\title{
Exploring the Work Paths of Smart Party Building for the Private Colleges and Universities in the New Era
}

\author{
Zhengwei Zhang ${ }^{1, *}$ and Mengyi Zhu ${ }^{1}$
}

\author{
${ }^{1}$ College of Continuing Education, Xi'an Siyuan University, Xi'an, 710038, China \\ *Corresponding author. Email: 396078600@qq.com
}

\begin{abstract}
Under the background of the "Internet +" era, the rapid development of the Internet and information technology have provided new opportunities and challenges for the party building work of private universities. "Internet + party building" work mode helps to improve the traditional party building. Through big data, cloud computing and artificial intelligence, we can carefully design the party work organization management mode, fully open the communication channels with teachers and students party members, extend the length and depth of party management, and actively explore the private university "wisdom party" work innovation path. In this context, we need to build a cloud platform for the practice of "smart party building" in private universities, to improve the comprehensive quality of "smart party building" workers in private universities, and to continuously improve the "smart party building" management system in private universities. Changing thinking and innovating mechanism are of contribution to providing useful solutions to promoting the "smart party building" work in the private colleges and universities.
\end{abstract}

Keywords: "Internet +", private colleges and universities, smart party building, innovation path

\section{INTRODUCTION}

At present, under the background of the "Internet + " era, the new generation of information technology represented by cloud computing, big data, the Internet of Things, mobile technology, and artificial intelligence is substantially changing the information transmission mode, production and life mode and national social governance mode of human society. The arrival of the information age, means a greater span of social change and the opening of a new era of network politics. It will profoundly change our social form, cultural tradition, living habits, organization and behavior, and deeply affect the party construction. Under this new situation, the working mode of "smart party building" in private colleges and universities has been gradually formed and developed continuously, thus opening up a new situation of party building work.

\section{THE BASIC CONCEPT OF SMART PARTY BUILDING WORK IN PRIVATE COLLEGES AND UNIVERSITIES}

As the core driving force of the new generation of industrial reform and scientific and technological revolution, artificial intelligence has gathered new technologies and theoretical achievements such as big data, cloud computing, mobile Internet, sensing network, cognitive science and brain science. This new approach sets off a new wave of the fourth industrial revolution of mankind, and is being widely used to all walks of life in society. Higher education is an important area of using the artificial intelligence empowerment. From the perspective of national policies, the State Council of the State Council issued the Development Plan of the New Generation of Artificial Intelligence in 2017, which proposed to "accelerate the in-depth application of artificial intelligence" and listed "intelligent education" as the primary task in the construction of an intelligent society. In 2018, In 2018, the Ministry of Education issued the Action Plan in Institutions of Higher Learning to advocate to "accelerate the innovative application of artificial intelligence in the field of education, and use intelligent technology to support the improvement of educational governance capacity". From the perspective of practical application, many universities in China are actively using artificial intelligence technology to promote teaching and management reform. Some colleges and universities have crudely realized the "intelligent recommended learning content and automatic guidance", "scale automatic correction and personalized feedback", which proposed the education intelligent robot, learning information intelligent management, online virtual faculty adaptive learning application of higher education new forms, new forms, thus enhancing the sharing ability of high-quality higher education resources. The rapid development of artificial intelligence technology brings grass-roots Party organizations in private colleges and universities into the era of "intelligent governance", and the application of artificial intelligence to improve the organization power of grass-roots Party organizations in private universities has gradually become an important development direction to optimize the governance of grass-roots Party organizations in private colleges and universities [1]. 


\begin{abstract}
"Smart party building" in private colleges and universities is an innovative party building work that fully integrates the content of the party building work with the Internet operation mode. Traditional party building work needs to be carried out face to face, so it has to be carried out in the same place and at the same time, so it is easy to be limited by the time and space. "Internet $+"$ has brought new possibilities to the traditional form of party building work and has effectively solved the time and space restrictions of party building work. The work of "smart party building" in private colleges and universities can maximum use modern information technology to optimize and integrate scattered and independent information. Thus, private colleges and universities can realize the unification, intelligence and intelligent party building information of colleges and universities through smart party building.
\end{abstract}

\section{THE NECESSITY OF "SMART PARTY BUILDING" IN PRIVATE COLLEGES AND UNIVERSITIES}

\subsection{The Changes in of the Times Promotes the Innovation of Traditional Party Building Models}

Today is an era of informatization and data transformation. The traditional party building model has been unable to adapt to the development of the society. The application of the "smart party building" platform is very necessary for the smooth development of the party building work in private colleges and universities. Data in recent years show that with the increase of the number of party members in private colleges and universities, the workload of party building has increased, and the personnel engaged in party building management is heavy. Most party building workers in private colleges and universities hold several jobs. If they continue to use the traditional party building model, it may lead to a sharp decline in the efficiency of party building work and be out of touch with the society. Therefore, it is urgent to take the "Internet + " as the basic platform to carry out the "smart party building" work. "smart party building" is not only just a software, but also an important way to strengthen the political and ideological education of Party members in colleges and universities. It can not only strengthen the communication between party members on the "smart party building" platform, but also understand the needs of the masses on the platform, so as to clarify the direction of the Party's work. "smart party building" can also help party members in private colleges and universities to strengthen social practice, combine with practical life, and effectively improve the practical ability of party members. Therefore, the intelligent party building management has gradually become the party's internal management mode.

\subsection{The Innovative Model of "Smart Party Building" Is More in Line with the Living and Learning Habits of Private College Students}

Dynamic monitoring and instant response "intelligent party building" are the party building activities of delivering real-time party building information technology based on network technology. The activities are characterized by the immediacy of information transmission and the initiative of learning mode. After receiving the information, the learners take the initiative to click, listen and watch at the same time. The use of this feature of intelligent party building makes it easier for the learners to strengthen their memory and take the initiative to participate in the learning. At the same time, the party building work will be integrated into the daily life of the learners, which is conducive to grasping of the policy more accurately.

The biggest problem in the traditional party building work comes from the lack of participants' interaction and insufficient communication. Due to the support of the platform, "intelligent party building" has more diversified interaction methods, and it is easier for participants to open their hearts to fully participate in the interaction. At the same time, the convenience of "intelligent party building" lies in its participation characteristics at any time. Participants can participate in the party building discussion or express opinions at any convenient time. In addition, "smart party building" does not need fixed places and fixed equipment, so participants can use ordinary mobile phones and other mobile devices to participate in it, reducing the threshold of participation in party building activities in private colleges and universities.

The characteristics of the full sharing of information resources makes the "smart party building" move the main position from online down to online, which is an important attempt and innovation for the party building work. The Internet connects hundreds of millions of terminals together, and this initiative is that the synchronous sharing of information becomes possible. Taking advantage of this information sharing, "intelligent party building" can break the original disadvantages of information asymmetry, and all kinds of party building information can be transmitted to the party building participants anytime and anywhere. At the same time, participants can also constantly exchange and supplement information, so that participants can understand the theory and knowledge of party building in the dynamic process, and can quickly understand their own knowledge deficiencies, and improve the deficiencies in the work in time [2].

\section{THE PROBLEMS EXISTING IN THE INNOVATION OF "SMART PARTY BUILDING" IN PRIVATE COLLEGES AND UNIVERSITIES}

At present, although some private colleges and universities are trying to promote the "wisdom party" work platform, in 
the function positioning and optimization measures, especially for the party work content integration, there does not reflect the technical advantages of intelligence and information. In addition, the content lacks innovation, and the operation mechanism also needs to be optimized, which affects the promotion effect of the "smart party building" work.

\subsection{The Application Technology of "Smart Party Building" in Private Colleges and Universities Needs to Be Innovated}

As the crystallization of modern technology, "smart party building" needs to constantly optimize and innovate the application software and hardware equipment, so as to be in line with the Internet technology and reflect the application advantages of the "smart party building" platform. However, on the one hand, the private colleges and universities are restricted by capital; on the other hand, the private colleges and universities lack an excellent information technology team to provide technical support for the stable operation of the "smart party building" platform, which will affect the quality and efficiency of the party building work in the private colleges and universities. With the rise of various Internet social platforms, application platforms also attach more importance to communication efficiency, and create a smooth and comfortable communication channel for users. As the link between the party organizations of private colleges and universities and the members of the grass-roots party organizations, the "smart party building" platform needs stable communication channels when transmitting the innovative spirit and communication. However, at the present stage, the "smart party building" platform of private colleges and universities lacks relevant functions. The platform can only unilaterally pass on the members but can not effectively absorb the suggestions and opinions of the members, which will make the "smart party building" platform of colleges and universities lose its original roles [3].

\subsection{The Quality of "Smart Party Building" Personnel Needs to Be Improved}

The ability level and comprehensive quality of smart platform construction staff in the grass-roots party building work in private colleges and universities directly affect the role of smart party building platform. However, through the analysis of the work ability and quality of the "smart party building" platform personnel, there are uneven good and bad conditions. Some middle-aged and elderly party building staff's information processing ability and computer application ability are relatively weak, and they are prone to resistance due to the weakness in the use of smart cloud platforms. Although the young party building staff are skilled in network technology and information processing ability, there can be excessive use. In addition, the construction of the platform provides greater convenience for the grassroots party building work. The release of much information is carried out through the platform, and the face-to-face communication time between the cadres is reduced, which is not conducive to the construction of a good relationship between the cadres and the masses.

\subsection{The Management System for the Construction of the "Smart Party Building" Platform in Private Universities Needs to Be Improved}

In the construction of grass-roots Party organizations in private colleges and universities, the "smart party building" is still in the primary stage without too many systems that can be referred to, and thus their own system construction is not perfect. Through the analysis of the "smart party building" management system under the background of "Internet +", we found that it is not positive and perfect in the system construction. At the same time, there is no unified standard, which results in the efficiency of party building management in private colleges and universities. At present, there are no national laws and regulations on the construction of the party building cloud platform. In addition, the legal awareness and knowledge of the grass-roots party building platform in private colleges and universities are weak, and the definition of party affairs information disclosure and confidential protection are still unclear, thus leading to the negative construction effect of the new mode of "smart party building" in private colleges and universities [4].

\section{THE INNOVATIVE PATHS OF "SMART PARTY BUILDING" WORK IN PRIVATE COLLEGES AND UNIVERSITIES}

\subsection{Building a Cloud Platform for fhe Practice of "Smart Party Building" for College Students in Private Universities}

smart party building platform is based on "Internet + " technology. With the help of computers, mobile phones, tablets and other electronic terminal equipment, it needs sufficient special funds to support and allocate professional teams to build the party affairs work platform. The "three meetings and a lesson", theme party day, party fee payment, branch exchange, work assessment, publicity and education, party member development and other work can be integrated with the functional modules to realize information dissemination, data statistics, party affairs information management, free from time and space restrictions, real-time user interaction and other functions. By using the VR virtual reality technology, holographic image technology, integrating the traditional propaganda 
video, electronic picture album, language interpretation guide map, online reservation and other technologies, a variety of kinds of red education resources offline can be moved to online to create a new VR smart party building platform. The Party's development course, major historical events, and great achievements can be vividly presented through the platform, so that Party members are immersive and have a deeper understanding of the essence of patriotism education. At the same time, it also solves the lack of interaction and insufficient vividness of traditional online resources.

After the establishment of the smart party building platform, many contents carried out by grass-roots Party organizations can be transferred to the platform, and Party members can use mobile terminals to learn, interact and communicate anytime and anywhere. The platform can provide a variety of forms of learning, such as text, video, audio, pictures, and rich learning content like video resources that can link TV series, news, micro video, movies and so on. In terms of the information communication mode, the intelligent party building platform has changed the single one-to-many communication form of traditional media. On the basis of no time and space restrictions, it realizes the two-way interaction between information communicators and recipients, which not only broadens the breadth of information, but also increases the depth of information communication. Rich learning resources, flexible learning forms and diversified communication methods can enhance the party member's learning interest of the party members, enhance the learning effect, enhance the theoretical cultivation of the student party members, and promote the establishment of a learning-oriented party organization [5].

\subsection{Improving the Comprehensive Quality of the "Smart Party Building" Workers in Private Colleges and Universities}

Private colleges and universities should attach importance to cultivating the comprehensive quality and working skills of party building workers, and give full play to their leading and promoting roles in the construction of a three-dimensional mode of intelligent party building. First of all, private colleges and universities should pay attention to improving the comprehensive quality and work skills of the school party building workers. Private colleges and universities should improve the training mechanism of party building workers, innovate the training methods and assessment and other aspects, help party building workers to develop the habit of informationized party building work, and improve their skills level of using information technology to carry out various party building work. Secondly, the party building workers in private colleges and universities should address the gaps between themselves and the excellent party building workers in colleges and universities, clarify the importance of improving their comprehensive quality and information technology application skills from the ideological level, actively learn relevant information technology knowledge, and lay a foundation for the use of information technology to carry out three-dimensional party building work. Finally, private colleges and universities should also explore outstanding party building talents among college student party members, enrich the party building work team, promote the overall improvement of the comprehensive quality of party building workers, and provide correct guidance for the construction of the three-dimensional mode of intelligent party building [6].

\subsection{Continuing to Improve the Management System of "Smart Party Building" in Private Colleges and Universities}

As the network world is not a predominant place, we should constantly strengthen the management level to make the network technology to truly serve the party building work, and even become the main body of the party building work. The management level here namely refers to the processing ability of the network information, but also refers to the development and maintenance ability of the network functions, including the service wisdom and enthusiasm of the "smart party building" management personnel in private colleges and universities. The improvement of the management level is the key to make the "smart party building" deeply rooted in the hearts of the people, but also to let the "smart party building" participants in private universities be more willing and actively participate in the smart party building activities. Therefore, the sign of measuring the success of the "smart party building" is the enthusiasm and initiative of the participants. And what determines the enthusiasm and initiative of the participants is the service level of the "smart party building" platform . The service of "smart party building" should include planning in advance, tracking during events, and collecting feedback afterwards, etc. Only by strengthening the technical level and management level at the same time can the hardware and software level be fully given full play, and then the efficiency of the "smart party building" platform of private colleges and universities can achieve the best effect. These endeavors will provide accurate and reliable data support for the management and decision-making of "smart party building", ensure the positive energy and vitality of the platform content of the "smart party building" platform, and guide Party members to move forward in the right direction.

\section{CONCLUSION}

In conclusion, under the background of "Internet +", information technology provides a more practical and more convenient ways for the "smart party building" platform of private colleges and universities, which promotes the education, management and service of Party 
members to keep pace with the times. With the innovation and improvement of the "smart party building" platform, it needs to promote the development of Party building work in private colleges and universities, enhance the vitality of Party building work, promote the progress of grass-roots teachers, students and Party members in private colleges and universities, and ensure that the grass-roots Party organizations in private colleges and universities are more cohesive and effective. This not only brings new vitality to the party building work, but also plays a positive role in the development of education and teaching as well as the daily work in private colleges and universities. Also, it is the significance of the new exploration of the "smart party building" work.

\section{ACKNOWLEDGMENT}

This work was supported by the 2020 major theoretical and practical problem research project of the social science industry in Shaanxi Province - Practice and theory of party construction in private universities in the new era (Project No.: 2020Z399).

\section{REFERENCES}

[1] Zeng Xiaojun, Huangs Daqian. Exploration on the Improvement of Organizing Capacity of Grassroots Party Organizations in Private University in the View of Artificial Intelligence [J]. Journal of Huanghe S\&T

University, 2021 (12): 29-33.
[2] Yang Zhenling. Innovative Research on Intelligent Party Building in "Internet+" Colleges and Universities [J]. Journal of Liaoning Economy Vocational and Technical College, 2021 (4): 047-049.

[3] Jia Haitao, Chen Liang. Function positioning and measures of "smart party building" under the background of "Internet + " [J]. Journal of Inner Mongolia University of Finance and Economics, 2021(5): 32-35.

[4] Li Hang. Research on the Construction of Cloud Platform for smart party building of University Grassroots Party Organizations in the "Internet +" Era [J]. Party Building Research, 2021: 114-115.

[5] Yan Peisheng, Li Yingyun, Xu Zhongbiao. Exploring the practice path of the College Students' Party Building Cloud Platform under the vision of "smart party building" [J]. Cultural Expo, 2021: 104-105.

[6] Zheng Binbin. Reflections on the Construction of Three-Dimensional Model of smart party building in Private Colleges and Universities[J]. Journal of Changzhou Institute of Technology (Social Science Edition), 2021(5): 139-140. 